\title{
Agrobacterium-mediated transformation of the wild orchid Cattleya maxima Lindl
}

\author{
Cueva-Agila Augusta Y., ${ }^{1, *}$, Cella Rino ${ }^{2}$
}

Edited by

Juan Carlos Salcedo-Reyes

(salcedo.juan@javeriana.edu.co)

1. Departamento de Ciencias Biológicas, Universidad Técnica Particular de Loja, Loja, Ecuador.

2. Department of Biology and Biotechnology. University of Pavia, Via Ferrata 9, 27100, Pavia, Italy.

*acueva@utpl.edu.ec

Received: $07-07-2017$

Accepted: 01-03-2018

Published on line: 22-03-2018

Citation: Cueva-Agila AY, Cella R. Agrobacterium-mediated transformation of the wild orchid Cattleya maxima Lindl,

Universitas Scientiarum, 23 (1): 89-107, 2018. doi: 10.11144/Javeriana.SC23-1.amto

Funding:

UTPL and SENESCYT

Electronic supplementary material: N.A.

OPEN ACCESS

\begin{abstract}
Protocorms are unique anatomical structures; they are akin to rhizoids and are formed by young orchid seedlings under physiological conditions. Explanted orchid tissues produce similar structures called protocorm-like bodies (PLBs) when exposed to appropriate in vitro growing conditions. Both the propagative nature of PLBs and the easiness by which they can be generated, make these structures an attractive alternative to seed-mediated production for growing large numbers of plants. To increase somatic embryogenesis and optimize the procedure, PLBs of Cattleya maxima were transformed using the Agrobacterium tumefaciens method. The T-DNA carried a Hygromycin-resistance gene, a visible marker (GFP5-GUSA) and a rice gene encoding the Somatic Embryogenesis Receptor Kinase, deemed to be important for somatic embryogenesis. Treated PLBs generated somatic embryos developing Hygromycin-resistant plantlets. The insertion of T-DNA was confirmed by PCR, and GFP expression was observed using a fluorescent stereomicroscope. Transformed Cattleya maxima PLBs were more efficient in forming somatic embryos (60 - 80\%) than untransformed controls (45 - 57\%), and this contrast was maximized in hormone-free, Murashige and Skoog (MS) medium (80\% of the transformed plants compared to $57 \%$ of the untransformed ones). This finding supports the notion that SERK plays an important role in Orchid embryogenesis.
\end{abstract}

Keywords: Protocorm-Like-Bodies; Transformation; Orchids; pCAMBIA; SERK; Agrobacterium tumefaciens

\section{Introduction}

The Orchidaceae is the largest vascular plant family in Ecuador, with nearly 4000 species, and is of economic importance for this country due to its significant share in the international ornamental plant market (Simpson 2006). 
Cattleya is one of the most noted genera of the family, for its popularity and richness of colors (Krapiec 2003). One native representative species of the genus is Cattleya maxima (Dodson \& Escobar 2005). Unfortunately, an intense specimen harvest, linked to habitat loss and deforestation threatens most native and endemic Ecuadorian orchid species (Dodson 2005). To counter this situation, ex situ clonal propagation methodologies for orchids are being developed (Cuoco \& Cronan 2009). For instance, several techniques of clonal propagation have been developed for the genus Cattleya (reviewed by Arditti 2008; Krapiec 2003). Transgenesis is a powerful tool to aid the success of clonal propagation of orchids. Pioneering work in the early eighties (Fraley et al. 1983) paved the way for the production of transgenic plants engineered for several purposes (Deo et al. 2010). Currently, successful orchid transformation protocols rely on an efficient regeneration procedure based on Somatic Embryogenesis (SE) and on culture conditions favoring the formation of the specific structures called Protocorm-Like-Bodies (PLBs), as a prerequisite for optimal clonal propagation (Young et al 2000, Texeira et al 2006, Cueva et al 2014).

During SE, differential expression of several genes takes place (Chugh \& Paramjit 2002). However, only few of the differentially expressed genes are considered embryogenesis-specific (Ikeda et al. 2003). The Somatic Embryogenesis Receptor-like Kinase (SERK) gene, is one of such genes expressed during SE as well as in zygotic embryogenesis. SERK expression is characteristic of embryo-forming masses in induced carrot suspension cultures (Schmidt et al. 1997). Homologues of carrot SERK have been described in different species and are encoded by small gene families of 1-6 members (described in Cueva et al 2012). In rice Oryza sativa, two SERK genes have been identified, OsSERK1 and OsSERK2 (Ito et al. 2005). Presumably, by modulating the expression of genes such as SERK during SE, the success of clonal propagation procedures could be improved. However, for orchids, and particularly for those of the genus Cattleya, reaching to this point first requires the development of the appropriate transgenesis toolkit.

Transgenic orchid production has been reported only for a few orchid genera (Men et al. 2003). Agrobacterium tumefaciens-mediated and microprojectile particle bombardment (biolistic protocol) have been the most successfully used methods for orchid transgenesis (Deo et al. 2010, Texeira da Silva et al. 2011). The biolistic method is thus far the most employed approach for orchid transformation, as in the genera Dendrobium (Men et al. 2003, Kuehnle \& Sugii 1992, Chia et al. 1994, Yu et al. 1999, Tee et al. 2003), Phalaenopsis, Cymbidium (Yang et al. 1999), Cattleya, Brassia, and Doritaenopsis (Knapp et al. 2000). The Agrobacterium-mediated method 
has been used for Dendrobium (Wasana et al. 2015, Men et al. 2003, Yu et al. 2001), Phalaenopsis (Belarmino \& Mii 2000, Chai et al. 2002, Mishiba et al. 2005, Sjahril \& Mii 2006), Cymbidium (Chen \& Chang 2002, Chin et al. 2007), Oncidium (Liau et al. 2003), Vanda (Pavallekoodi et al. 2014), Erycina (Lee et al. 2015), and Cattleya (Zhang et al. 2010). Compared to the biolistic method, Agrobacterium-mediated transformation offers the following advantages: delivery of a lower transgene copy number, lower level of transgene rearrangement, transfer of relatively large segments of DNA, and no special equipment requirements (Hei et al. 1994, Cheng et al. 1997). The Agrobacterium method proved to be efficient for most dicotyledonous species, but it appears to be less suited for monocots. The genus Cattleya was found to be recalcitrant to Agrobacterium-mediated transformation. Only one successful application of the method has been reported for a commercial Cattleya variety (CM2450) (Zhang et al. 2010).

Selection of transformants relies on the use of the two types of markers: reporter genes and selectable markers. The most commonly used reporter genes for orchid transformation are: $\beta$-glucuronidase (GUS), the anthocyanin pigmentation gene, the firefly luciferase gene, and the Green Fluorescent Protein (GFP) gene. As for selectable markers, several antibiotic, or herbicide resistance genes have been utilized, including neomicyn phosphotransferase (nptII), hygromycin phosphotransferase ( $h p t)$, and phosphinotricinacetyltransferase (bar) (Suwanaketchanatit et al. 2007). However, orchid cells are normally poorly sensitive to most selective agents. For instance, a high concentration of gentamicin and kanamycin $\left(600 \mathrm{mg} \mathrm{l}^{-1}\right)$ was used to eliminate untransformed cells and plants of various Dendrobium species (Chia et al. 1994). Instead, hygromycin (Hyg) was reported to be a reliable selective agent for the transformation of orchids (Men et al. 2003, Belarmino \& Mii 2000, Chai et al. 2002, Liau et al. 2003, You et al. 2003, Liao et al. 2004). In this study, an Agrobacterium-mediated protocol for the transformation of C. maxima was established as a mean to promote the overexpression of the Os-SERK gene on SE in this orchid species.

\section{Materials and Methods}

\section{Plant Material}

Protocorms of C. maxima were obtained from seeds germinated in vitro on half strength Murashige \& Skoog (MS) medium containing $20 \mathrm{~g} / \mathrm{L}$ of sucrose and grown at $57 \mu \mathrm{mol} \mathrm{m} \mathrm{m}^{-2} \mathrm{~s}^{-1}$ photon flux density (fluorescent lamps of $40 \mathrm{~W})$, at $21 \pm 2^{\circ} \mathrm{C}$ with a $12 \mathrm{~h}$ photoperiod. 


\section{Plasmid Construction}

The well-characterized monocot SERK1 gene from rice (OSSERK1) (Kikuchi et al. 2003) was used in this study. The complete OsSERK1 cDNA (Clone, PS-JO33117E16-National Institute of Agricultural Sciences NIAS-Japan) was amplified using primers bearing the SpeI and SphI restriction sites (SpeI-OsSERK-fw: 5'ACT AGT ATG GCG GCG CAT CGG TGG 3' and SphI-OsSERK-rv: 5'GCA TGC TCA CCT CGG CCC TGGA TAG 3') Subsequently, it was cloned in the pGEM ${ }^{\circledR}-T$ Easy vector (Promega). The DNA was then digested with SpeI and SphI and subcloned in an pFF19 vector (Timmermans et al. 1990) that contains $35 S$ promoter and terminator sequences of the cauliflower mosaic virus (CaMV) using XbaI and SphI sites. The recombinant pro35S::OsSERK1::ter35S cassette was then digested with HindIII and EcoRI and subcloned into a pCAMBIA 1301 vector (Center for the Application of Molecular Biology to International Agriculture, Australia) harboring the hygromycin resistance marker gene (hpt) (Chin et al. 2007, Kei-ichiro et al. 2005). The recombinant cassette was introduced in two A. tumefaciens strains (GV3101/pMP90) by electroporation, with the following conditions: $2.5 \mathrm{kV}, 25 \mu \mathrm{F}, 400 \Omega$. The map of the recombinant T-DNA is shown in Fig. 1.

\section{Assessment of A.tumefaciens strains}

The transformation efficiencies of the A. tumefaciens strains GV3101/pMP90 (Koncz \& Schell 1986) and EHA105 (Hood et al. 1993) were assessed. GV3101/pMP90 carries a gentamycin-resistance gene on the Ti plasmid and a rifampicin-resistance gene on the chromosome, and EHA105 carries a gene for resistance to rifampicin on its chromosome. Three-month old protocorms, in eight replicates (flasks), were transformed with each strain.

\section{Inoculation and co-cultivation}

A. tumefaciens was grown for $2 \mathrm{~d}$ at $28^{\circ} \mathrm{C}$ in $5 \mathrm{~mL}$ of $\mathrm{LB}$ medium containing $100 \mathrm{mg} / \mathrm{L}$ of kanamycin and $100 \mathrm{mg} / \mathrm{L}$ of rifampicin. The culture was transferred to $50 \mathrm{~mL}$ of LB medium and cultured overnight at $28^{\circ} \mathrm{C}$. Four hours prior to transformation, acetosyringone at a final concentration of $200 \mu \mathrm{M}$ was added. After centrifugation at $3000 \mathrm{rpm}$, the pellet was resuspended in $20 \mathrm{~mL}$ of MS medium. About $20 \mathrm{~mL}$ of resuspended bacteria were added to each plate containing pre-cultured protocorms and incubated at room temperature for $3 \mathrm{~h}$. The protocorms were blotted dry on sterile filter paper and co-cultivated at $25^{\circ} \mathrm{C}$ in the dark for $4 \mathrm{~d}$ in MS medium containing $200 \mu \mathrm{M}$ acetosyringone. 


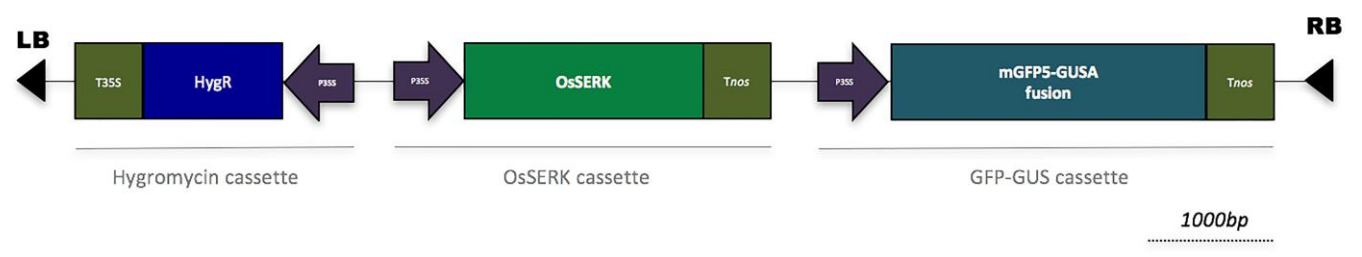

Figure 1. Schematic structure of the T-DNA region in the constructp CAMBIA1301-OsSERK. LB-Left border, RB-Right border, T35S: 35SCaMV terminator, P35S: 35SCaMV promoter. HygR (hygromycin phosphotransferase gene), OsSERK- Orysa sativa Somatic Embryogenesis Receptor like Kinase Gene; mGFP5-GusA fusion. All the coding regions are under the control of CaMV35S promoter and CaMV35S terminator. The orientation of each single cassette is indicated in the figure.

\section{Selection of Transgenic PLBs and plant regeneration}

To eradicate $A$. tumefaciens after co-cultivation, the protocorms were washed with MS medium containing $200 \mathrm{mg} / \mathrm{L}$ of timentin, transferred to MS medium with $200 \mathrm{mg} / \mathrm{L}$ of timentin and $50 \mathrm{mg} / \mathrm{L}$ of cefatoxime and subcultured weekly for five additional weeks. A preliminary test using $C$. maxima PLBs (primary) showed that the minimal selective concentration of hygromycin was $20 \mathrm{mg} / \mathrm{L}$ over a period of two months (data not shown). In this study, the selection was extended to five months, with monthly transplant to fresh medium.

\section{PCR screening of transformants}

DNA was extracted from $30 \mathrm{mg}$ of leaves, using the Wizard ${ }^{\circledR}$ SV Genomic DNA Purification System (Promega) and following the manufacturer's instructions. Genomic DNA (8 ng) was directly used for PCR screening with primers annealing on the OsSERK1 gene (5'-TGCTCGTCTAGCCAATGATG-3'), and.

(5'-ATGAGGGCCAAGCTCTACC-3'). PCR amplification was carried out in an Applied Biosystem Thermocycler as follows: $94^{\circ} \mathrm{C}(5 \mathrm{~min}), 32$ amplification cycles $\left(94^{\circ} \mathrm{C}\right.$ for $30 \mathrm{~s}, 58^{\circ} \mathrm{C}$ for $30 \mathrm{~s}, 72^{\circ} \mathrm{C}$ for $\left.1 \mathrm{~min}\right)$ and a final extension cycle of $5 \mathrm{~min}$ at $72{ }^{\circ} \mathrm{C}$ using GoTAQ polymerase (Promega, Spain). 


\section{GFP Analysis}

The pCAMBIA-OsSERK1 construct contains a mGFP5-gusA fusion under the control of 35SCaMV promoter and terminators for visual selection of transformants. Detection of GFP epifluorescence was performed using a fluorescent stereomicroscope (Olympus DFPL 0,5X-4, Japan) equipped with a U- RFL-T Filter (Olympus). Images were taken with a Camedia camera (C5060 Olympus, Japan) connected to the stereomicroscope and adjusted using ImageJ software (Rasband, 2016)

\section{Somatic embryogenesis in transformed lines carrying OsSERK1}

A total of 80 leaf explants of transformed and control C. maxima plants were cultured either on MS hormone-free medium or MS medium containing TDZ $(0.3 \mathrm{mg} / \mathrm{L})$ or BA $(0.3 \mathrm{mg} / \mathrm{L})$. The percentage of developing somatic embryos was evaluated after $30 \mathrm{~d}$. The statistical significance of the results was assessed via F-test.

\section{Results and Discussion}

\section{Selection of transformed explants}

The hygromycin resistance marker gene was chosen because it was previously used for A. tumefaciens-mediated transformation of Oncidium species (You et al. 2003, Liao et al. 2004), and for Phalaenopsis hybrids along with a $\beta$-glucuronidase gene sequence (Belarmino \& Mii 2000, Chai et al. 2002, Mishiba et al. 2005, Chan et al. 2005). Based on these observations, in the present study we have used a pCAMBIA 1301 vector harboring gene sequences for hygromycin resistance, GUS (uidA), and GFP in addition to an OsSERK1 gene copy to evaluate its possible role in the stimulation of somatic embryo formation.

During the 5-month selection step, plants derived from PLBs, characterized by the presence of one or two leaves (Fig. 2a, white arrow) died after two months, while juveniles PLB without leaves formed calli producing new PLBs (Fig. 2b, black arrow) that further developed into plantlets (Fig. 2c). It is worth noting that the developmental stage of the explant is crucial for orchid transformation success. For instance, it was reported that for Oncidium the age of the plantlets used for transformation influenced hygromycin tolerance (Liau et al. 2003). Additionally, in a review (Texeira da Silva 2013) mentioned that coniferyl alcohol, which is known as a vir gene inducer, is present in PLB at a level higher than in any other tissues, thus suggesting that PLBs are ideal 
for Agrobacterium-mediated transformation. In this work, this observation is confirmed also for C. maxima.

\section{PCR and OsSERK1 gene analysis of putative C. maxima transformants}

After a month of growth on the MS selection medium, $89.5 \%$ of the of the PLBs had survived. To verify whether secondary PLBs were transformed, a PCR-based test was used to verify the presence of the OsSERK 1 gene. An expected fragment (612 bp) was observed in 4 out of the 30 putative transformants (Fig. 3). This low transformation efficiency (approximately $10 \%$ ), confirmed the need for a more stringent selection step to eliminate false positives. To this end, the selection time was prolonged to five months.
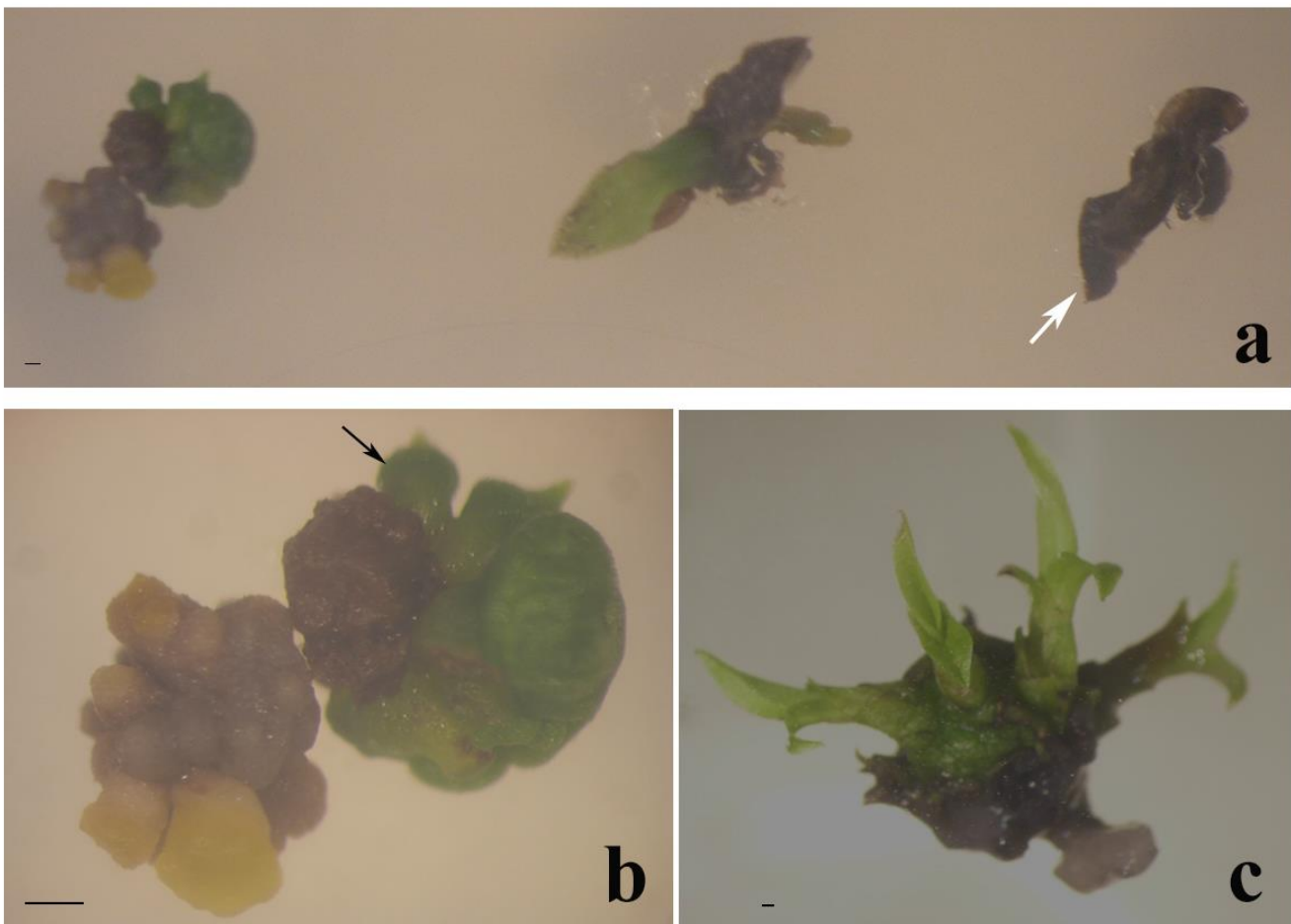

Figure 2. Selection of putative transformants of Cattleya maxima. a) Protocorms of different ages growing on the selection medium $\left(20 \mathrm{mg} \mathrm{L}^{-1}\right.$ hygromycin, MS). The white arrow indicates a dead protocorms.

b) Surviving protocorms on the same selective medium (black arrow).

c) Shoots developed six months after co-cultivation. (Bar $=0.5 \mathrm{~cm}$ ). 


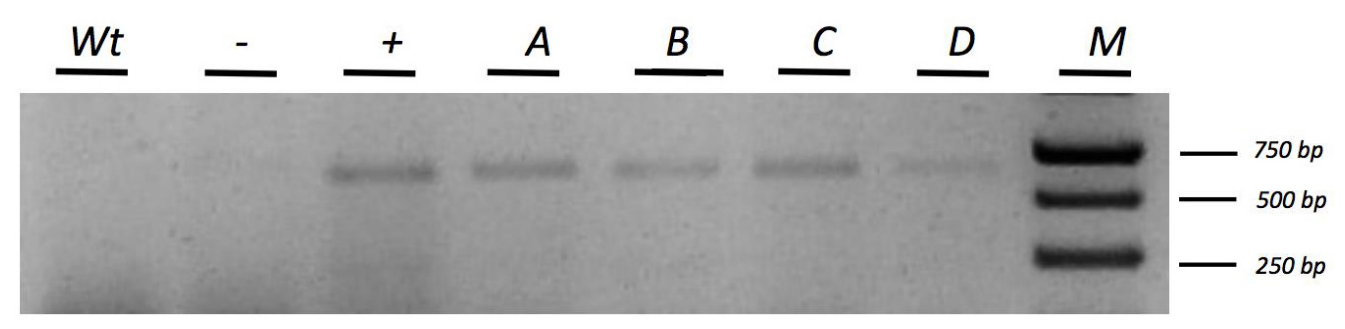

Figure 3. Control of the presence of OsSERK gene in transgenic lines. A band of the expected size (612bp) was observed in selected plants. As expected, the $612 \mathrm{bp}$ fragment failed to be amplified in both blank and wild-type, untransformed plant. "Wt" =Wild type plant "A, B, C, D" = selected plants “-” = blank, negative control “+” = pCAMBIA-OsSERK plasmid, positive control.

The ability to transfer a given T-DNA to a host cell depends on its chromosomal background (Yasmine \& Debener 2010), the efficiency of the two A. tumefaciens strains was assessed by evaluating the percentage of protocorms surviving to hygromycin selection. GV3101/pMP90 failed to give any transformant while EHA105 strain, typically used for monocot species, yielded $(7.4 \pm 1.8) \%$ viable PLBs after protracted following hygromycin selection.

The presence of GFP5-GUSA fusion protein in pCAMBIA-OsSERK1 offers the possibility to identify transformants by observing epifluorescence. After a growth period of five months on Hyg-selective medium, putative transformants were randomly screened. At inspection, all putative transformants presented normal phenotypes, and no signs of dwarfism were observed. Fluorescence was detected in $70 \%$ of both calli (Fig. 4) and regenerated plants (Fig. 5). No background fluorescence was observed in untransformed calli and plants (data not shown).

Table 1. Somatic embryogenesis responses of transformed and wild type $C$. maxima plants. *Percentage of leaves producing somatic embryos.

\begin{tabular}{cccc|}
\hline Medium & \multicolumn{3}{c}{ Somatic embryogenesis (\%)* } \\
& $\begin{array}{c}\text { Transformed } \\
\text { plants }\end{array}$ & Wild type & $\begin{array}{c}\text { F of Fisher } \\
\text { significance }\end{array}$ \\
\hline $\mathrm{MS}+0.3 \mathrm{mg} \mathrm{L}^{-1} \mathrm{TDZ}$ & $60 \pm 28$ & $51 \pm 14$ & 0.757 \\
\hline $\mathrm{MS}+0.3 \mathrm{mg} \mathrm{L}^{-1} \mathrm{BA}$ & $60 \pm 25$ & $45 \pm 6$ & 0.331 \\
\hline $\mathrm{MS}$ & $80 \pm 3$ & $57 \pm 3$ & 0.002 \\
\hline
\end{tabular}



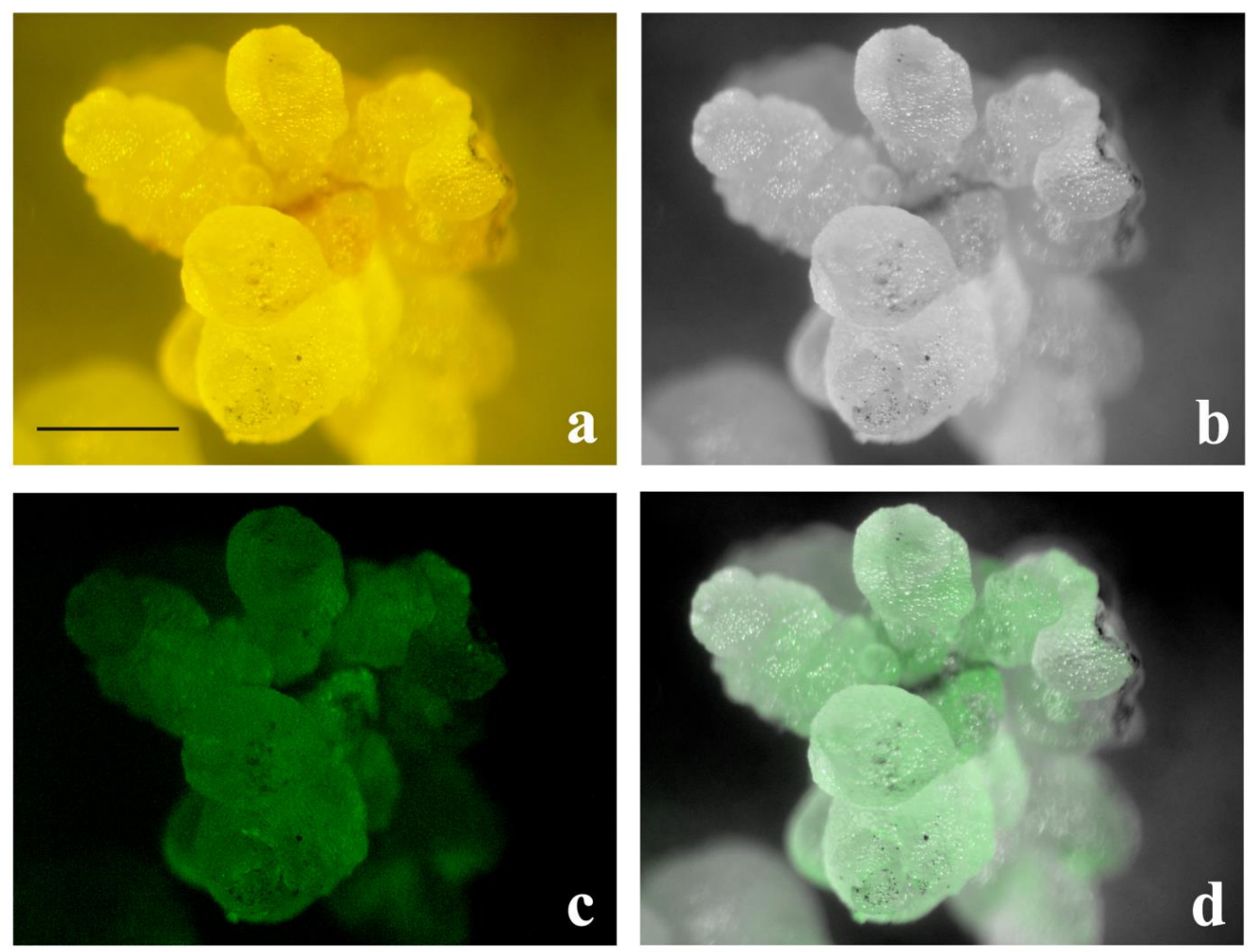

Figure 4. GFP-epifluoresence in a callus generated from a protocorm of C. maxima co-cultivated with $A$. tumefaciens. Panels a) and b) show a regenerated transformant examined using a fluorescence stereomicroscope. a) is in true color while, b) is the black-and-white version, c) GFP epifluorescence, $d$ ) overlay of $\mathbf{b})$ and $\mathbf{c})$. (Bar $=0.5 \mathrm{~cm})$

Somatic embryogenesis in transformed explants

A significantly higher percentage of embryos ( $80 \%$ compared to $57 \%$ ) were formed from in C. maxima leaf explants, containing the OsSERK1 cassette, obtained from plantlets regenerated from secondary PLBs (Fig. 2C) as compared to those derived from wild type plants when cultured on hormone-free MS medium (Table 1). Furthermore, the total number of embryos per leaf was significantly higher in leaves obtained from transformants grown on hormone-free MS medium compared to untransformed leaves: $2.3 \pm 0.7$ versus $1.5 \pm 0.2(\mathrm{~F}=0.022)$. Interestingly, the presence of TDZ or BA resulted in a reduced percentage of embryo formation (Table 1). Since it is well known that a proper balance of auxin/cytokinin stimulates embryogenesis in orchids (Novak et al. 2014) it is tempting to speculate that the external addition of cytokinins might interfere with the endogenous physiological auxin/cytokinin ratio necessary for somatic embryogenesis. 

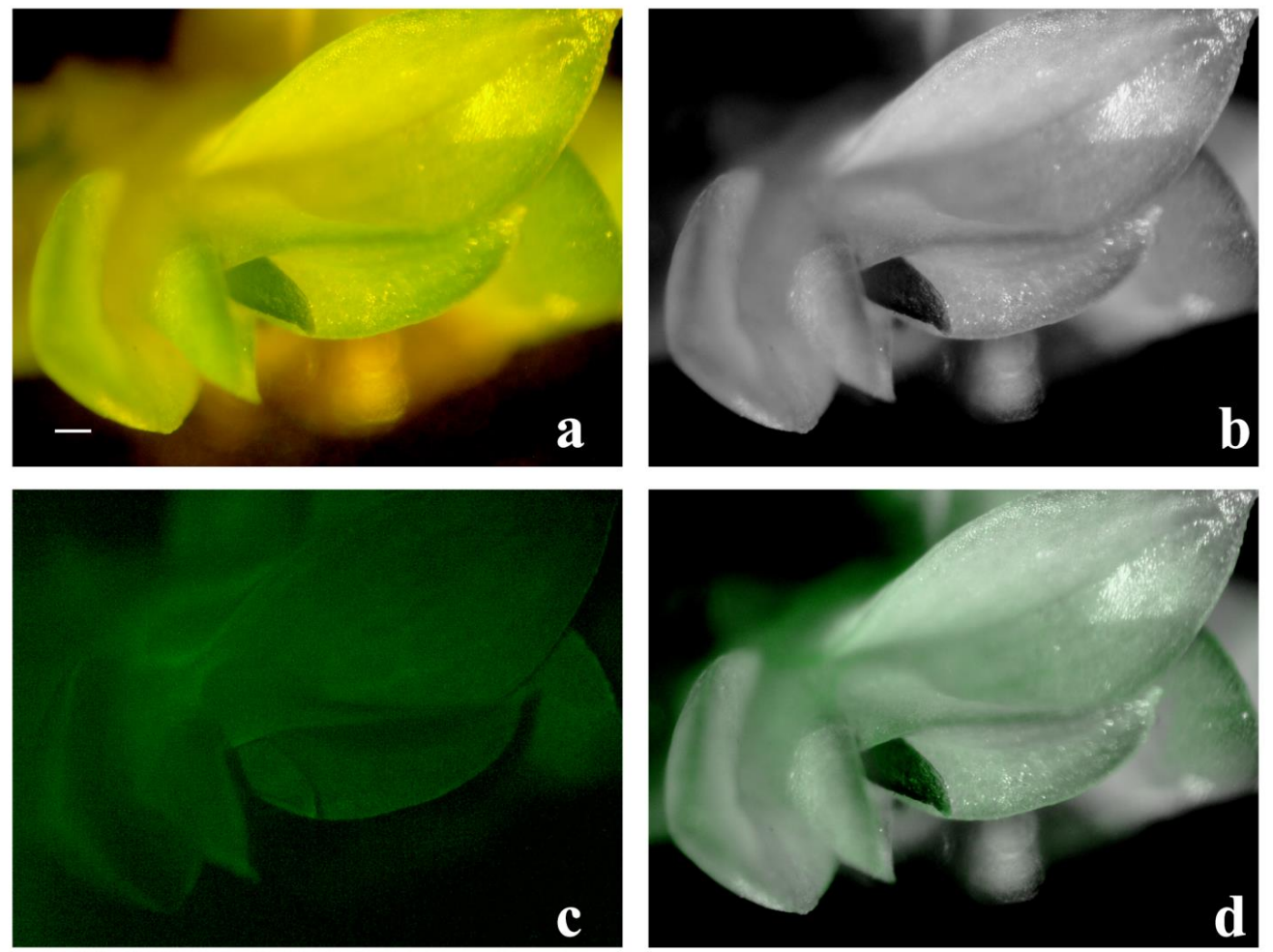

Figure 5. GFP epifluorescence in an eight-month regenerated plant of $C$. maxima. Panels a) and b) show a putative transformant examined using a fluorescence stereomicroscope; a) is in true color while b) is the black-andwhite version; panels c) shows epifluorescence in the sample and panel $\mathbf{d}$ ) shows the overlay of b) and c). No background fluorescence was observed in wild type plants (data not shown). (Bar $=0.5 \mathrm{~cm}$ ) 


\section{Conclusion}

In the present work, we describe a method for the stable transformation of the wild orchid C. maxima mediated by $A$. tumefaciens. We have also developed a method for the regeneration of transformed plants via somatic embryogenesis through a dedifferention-regeneration cycle that includes the formation of secondary PLBs. The higher number of embryos obtained from leaves containing recombinant heterologous OsSERK1 gene, as compared to untransformed plants, points to its involvement in orchid somatic embryogenesis.

\section{Acknowledgements}

The authors wish to thank Claudia Morandi for technical support and to two anonymous reviewers for their critical revision of this manuscript. This work is part of C-A. A.'s doctoral research project financed by UTPL and SENESCYT.

\section{Conflict of interest}

The authors declare that they have no affiliations with or involvement in any organization or entity with any financial interest in the subject discussed in this manuscript.

\section{References}

ArdittiJ.Micropropagation of Orchids. Second Edition. Blackwell Publishing, Oxford. UK. 2008.

Belarmino M, Mii M. Agrobacterium-mediated genetic transformation of a Phalaenopsis orchid, Plant Cell Reports, 19: 435-442, 2000. doi: $10.1007 /$ s002990050752

Chai ML, Xu CJ, Senthil KK, Kim JY, Kim DH. Stable transformation of protocorm-like bodies in Phalaenopsis orchid mediated by Agrobacterium tumefaciens, Scientia Horticulturae, 96: 213-224, 2002.

doi: 10.1016/S0304-4238(02)00084-5

Chan YL, Lin KH, Sanjaya, Liao LJ, Chen WH, Chan MT. Gene stacking in Phalaenopsis orchid enhances dual tolerance to pathogen attack, Transgenic Research, 14: 279-288, 2005.

doi: 10.1007/s11248-005-0106-5 
Chen J, Chang W. Effects of tissue culture conditions and explant characteristics on direct somatic embryogenesis in Oncidium 'GowerRamsey', Plant Cell Tissue and Organ Culture, 69: 41-44, 2002.

doi: 10.1023/A:1015004912408

Cheng M, Fry JE, Pang S, Zhou H, Hironaka CM, Duncan DR, Conner TW, WanY. Genetic transformation of wheat mediated by Agrobacterium tumefaciens, Plant Physiology, 115: 971-980, 1997.

Chia TF, Chan YS, Chua NH. The fire fly luciferase gene as a non-invasive reporter for Dendrobium transformation, Plant Journal, 6: 441-446, 1994.

doi: 10.1046/j.1365-313X.1994.06030441.x

Chin D, Kei-ichiro M, Masahiro M. Agrobacterium-mediated transformation or proto corms-like bodies in Cymbidium, Plant Cell Reports, 26: 735-743, 2007.

doi: 10.1007/s00299-006-0284-5

Chugh A, Paramjit K. Gene expression during somatic embryogenesisrecent advances, Current Science, 83: 715-730, 2002.

Cueva A, Concia L, Cella R. Molecular Characterization of a Cyrtochilum loxense Somatic Embryogenesis Receptor-Like Kinase (SERK) Gene Expressed during Somatic Embryogenesis, Plant Cell Reports, 31: 1129-1139, 2012.

doi: $10.1007 /$ s00299-012-1236-x

Cueva A, Guachizaca I, Cella R. Combination of 2,4-D and Stress Improved Indirect Somatic Embryogenesis on Cattleya maxima Lindl, Plant Biosystems, 149(2): 235-241, 2014.

doi: 10.1080/11263504.2013.797033

Cuoco L, Cronan J. Orchidaceae: Using a Globalized Commodity to Promote Conservation and Sustainable Economic Development in Southern Ecuador, Journal of Sustainable Forestry, 28: 799-824, 2009

Deo PC, Tyagi, Anand P, Taylor M, Harding R, Becker D. Factors affecting somatic embryogenesis and transformation in modern plant breeding, The South Pacific Journal of Natural and Applied Sciences, 28: 27-40, 2010.

doi: 10.1071/SP10002

Dodson C, Escobar R. Native Ecuadorian Orchids. Vol 5 Ed. Colina Livraria Editora Ltda. Medellín, Colombia. p. 1-11, 2005. 
Fraley R T, Rogers SG, Horsch RB, Sanders PR, Flick JS, Adams SP, Bittner ML, Brand LA, Fink CL, Fry JS, Galluppi GR, Goldberg SB, Hoffmann NL, Woo SC. Expression of bacterial genes in plant cells, Proceedings of the National Academy of Science. USA, 80(15): 4803-4807, 1983.

Hiei Y, Ohta S, Komari T, KumashiroT. Efficient transformation of rice (Oryza sativa L.) mediated by Agrobacterium and sequence analysis of the boundaries of T-DNA, The Plant Journal, 6(2): 271-282, 1994. doi: 10.1046/j.1365-313X.1994.6020271.x

Hood E, Gelvin S, Melchers L, Hoekema A. New Agrobacterium helper plasmids for gene transfer to plants, Transgenic Research, 2(4): 208-218, 1993.

Ikeda I, Mikihisa U, Shinobu S, Hiroshi K. Stress-induced somatic embryogenesis in vegetative tissues of Arabidopsis thaliana, The Plant Journal: for Cell and Molecular Biology, 34(1): 107-114, 2003.

Ito Y, Kazuhiko T, Nori K. Expression of SERK family receptor-like protein kinase genes in rice, Biochimica et Biophysica Acta (BBA) - Gene Structure and Expression, 1730(3): 253-258, 2005.

Kei-ichiro M, Chin D, Masahiro M. Agrobacterium-mediated transformation of Phalaenopsis by targeting protocorms at an early stage after germination, Plant Cell Reports, 24: 297-303, 2005.

doi: 10.1007/s00299-005-0938-8

Kikuchi S, Satoh K, Nagata T, et al. Collection, mapping, and annotation of over 28,000 cDNA clones from japonica rice, Science, 301: 376-379, 2003.

doi: $10.1126 /$ science. 1081288

Knapp JE, Kausch AP, Chandlee JM. Transformation of three genera of orchid using the bar gene as a selectable marker, Plant Cell Reports, 19(9): 893-898, 2000.

doi: $10.1007 /$ s002990000202

Koncz C, Schell J. The promoter of the TL-DNA gene 5 controls the tissue-specific expression of chimaeric genes carried by a novel type of Agrobacterium binary vector, Molecular and General Genetics $M G G$, 204(3): 383-396, 1986.

doi: $10.1007 / \mathrm{BF} 00331014$

Krapiec PV, Milaneze M, Pires M. Effects of different combinations of growth regulators for bud induction from seedlings of Cattleya walkeriana Gardner (Orchidaceae), Acta Scientiarum: Biological Sciences, 25(1): 179-182, 2003. 
Kuehnle AR, Sugii N. Transformation of Dendrobium orchid using particle bombardment of protocorms, Plant Cell Reports, 11(9): 484-488, 1992.

doi: 10.1007/BF00232696

Lee SH, Li CW, Liau CH, Chang PY, Lioa LJ, Lin CS, Chan MT. Establishment of an Agrobacterium-mediated genetic transformation procedure for the experimental model orchid Erycina pusilla, Plant Cell, Tissue and Organ Culture(PCTOC), 120(1): 211-220, 2015.

doi: 10.1007/s11240-014-0596-z

Liao LJ, Pan IC, Chan YL, Hsu UH, Chen WH, Chan MT. Transgene silencing in Phalaenopsis expressing the coat protein of Cymbidium Mosaic Virus is a manifestation of RNA-mediated resistance, Molecular Breeding, 13(3): 229-242, 2004.

doi: 10.1023/B:MOLB.0000022527.68551.30

Liau CH, You SJ, Prasad V, Hsiao HH, Lu JC, Yang NS, Chan MT. Agrobacterium tumefaciens-mediated transformation of an Oncidium orchid, Plant Cell Reports, 21(10): 993-998, 2003.

doi: 10.1007/s00299-003-0614-9

Men SZ, Ming XT, Liu RW, Wei CH, Li Y. Agrobacterium-mediated genetic transformation of a Dendrobium orchid, Plant Cell, Tissue Organ Culture, 75(1): 63-71, 2003.

doi: 10.1023/A:1024627917470

Mishiba K, Chin DP, Mii M. Agrobacterium-mediated transformation of Phalaenopsis by targeting protocorms at an early stage after germination, Plant Cell Reports, 24(5): 297-303. 2005.

doi: 10.1007/s00299-005-0938-8

Novak SD, Luna LJ, Gamage RN. Role of Auxin in orchid Development, Plant signaling \& Behavior, 9: 10, e972277, 2014.

doi: $10.4161 /$ psb.32169

Pavallekoodi G, Jessica JJA, Uddain J, Subramaniam S. AgrobacteriumMediated Transformation of the Recalcitrant Vanda Kasem's Delight Orchid with Higher Efficiency, The Scientific World Journal, ID 583934: 10, 2014.

doi: $10.1155 / 2014 / 583934$

Rasband, W.S., ImageJ, U. S. National Institutes of Health, Bethesda, Maryland, USA, https://imagej.nih.gov/ij/, 1997-2016. 
Schmidt ED, Guzzo F, Toonen MA, de Vries SC. A leucinerichrepeatcontainingreceptor-likekinasemarkssomaticplantcellscom petent to formembryos, Development, 124: 2049-2062, 1997.

Simpson M. Plant Systematics. Elsevier. Oxford, UK, 2006.

Sjahril R, Mii M. High-efficiency Agrobacterium-mediated transformation of Phalaenopsis using meropenem, a novel antibiotic to eliminate Agrobacterium, The Journal of Horticultural Science and Biotechnology, 81(3): 458-464, 2006.

doi: $10.1080 / 14620316.2006 .11512088$

Suwanaketchanatit C, Piluek J, Peyachoknagul, Huehne. High efficiency of stable genetic transformation in Dendrobium via microprojectile bombardment, Biologia Plantarum, 51: 720-727, 2007.

doi: 10.1007/s10535-007-0148-z

Tee CS, Maziah M, Tan CS, Abdullah MP. Evaluation of different promoters driving the GFP reporter gene and selected target tissues for particle bombardment of Dendrobium Sonia 17, Plant Cell Reports, 21: 452-458, 2003.

Teixeira da Silva JA, Singh N, Tanaka M. Priming biotic factors for optimal protocorm-like body and call usinduction in hybrid Cymbidium (Orchidaceae), and assessment of cytogenetic stability in regenerated plantlets. Plant Cell, Tissue and Organ Culture, 84: 135-144. 2006.

Teixeira da Silva JA, Chin DP, Van PT, Mii M. Transgenic orchids, Scientia Horticulturae, 130(4): 673-680, 2011.

Texeira da Silva J, Orchids: advances in tissue culture, genetics, phytochemistry and transgenic biotechnology, Floriculture and Ornamental Biotechnology, 7(1): 1-52, 2013.

Timmermans MC, Maliga P, Vieira J, Messing J. The pFF plasmids: cassettes utilising CaMV sequences for expression of foreign genes in plants, Journal of Biotechnology, 14(3): 333-344, 1990.

doi: 10.1016/0168-1656(90)90117-T

Wasana P, Chin D, Ntui V, Nakamura I, Masahiro M. High efficiency Agrobacterium-mediated transformation of Dendrobium orchid using protocorms as a target material, Plant Biotechnology, 32: 323-327, 2015.

doi: $10.5511 /$ plantbiotechnology.15.0804a

Yang J, Lee HJ, Shin DH, Oh SK, Seon J H, Paek KY, Han KH. Genetic transformation of Cymbidium orchid by particle bombardment, Plant Cell Reports, 18(12): 978-984, 1999

doi: $10.1007 /$ s002990050694 
Yasmine A, Debener T. Transient gene expression in rose petals via Agrobacterium infiltration, Plant Cell, Tissue and Organ Culture, 102(2): 245-250, 2010.

doi: $10.1007 /$ s11240-010-9728-2

You SJ, Liau CH, Huang HE, Feng TY, Prasad V, Hsiao HH, Lu JC, Chan MT. Sweet pepper ferredoxin- like protein (pflp) gene as a novel selection marker for orchid transformation, Planta, 217(1): 60-65, 2003.

Young PS, Murthy HN, Yoeup PK. Mass multiplication of protocormlike bodies using bioreactor system and sub sequent plant regeneration in Phalaenopsis, Plant Cell, Tissue and Organ Culture, 63(1): 67-72, 2000.

Yu H, Yang SH, Goh CJ. Agrobacterium-mediated transformation of a Dendrobium orchid with the class 1 knox gene DOH1, Plant Cell Reports, 20: 301-305, 2001

doi: $10.1007 /$ s002990100334

Yu Z, Chen M, Nie L, Lu H, Ming X, Zheng H, Qu L, Chen Z. Recovery of transgenic orchid plants with hygromycin selection by particle bombardment to protocorms, Plant Cell, Tissue and Organ Culture, 58(2): 87-92, 1999.

doi: 10.1023/A:1006334605947

Zhang L, Chin D, Mii M. Agrobaterium-mediated transformation of protocorm-like bodies in Cattleya, Plant Cell, Tissue and Organ Culture, 103(1): 41-47,2010

doi: $10.1007 /$ s11240-010-9751-3 


\section{Transformación mediada por Agrobacterium de la orquídea silvestre Cattleya maxima Lindl}

Resumen. Los protocormos son estructuras anatómicas únicas: son similares a los rizoides y se forman por vástagos jóvenes de orquídeas bajo condiciones fisiológicas. Los tejidos explantados de orquídeas producen estructuras llamadas Cuerpos Similares a Protocormos (PLBs) cuando están expuestos a condiciones apropiadas de crecimiento in vitro. Tanto la naturaleza propagativa de los PLBs como la facilidad con que se generan, hacen de estas estructuras una alternativa atractiva, frente a la mediada por semillas, para la producción de gran número de plantas en crecimiento. Para aumentar la embriogénesis somática y optimizar el procedimiento, se transformaron PLBs de Cattleya maxima usando el método de Agrobacterium tumefaciens. El T-DNA portaba un gen de resistencia a la Higromicina, un marcador visible (GFP5-GUSA) y un gen de arroz que codificaba para el receptor tipo quinasa de embriogénesis somática (SERK), considerado importante en la embriogénesis somática. Los PLBs tratados generaron embriones somáticos y desarrollaron plántulas resistentes a la Higromicina. La inserción del T-DNA se confirmó por PCR, y la expresión de GFP se observó usando un estereomicroscopio fluorescente. Los PLBs transformados de Cattleya maxima fueron más eficientes en desarrollar embriones somáticos (60-80\%) que los controles no transformados (45-57\%) y este contraste se maximizó en medio Murashige y Skoog (MS) libre de hormonas $(80 \%$ de las plantas transformadas en comparación con $57 \%$ de las no transformadas). Estos hallazgos apoyan la noción de que SERK juega un papel importante en la embriogénesis de orquídeas.

Palabras clave: Agrobacterium tumefaciens; Cuerpos Similares a Protocormos; Transformación; Orquídeas; pCAMBIA; SERK. 


\section{Transformação da orquídea silvestre Cattleya maxima Lindl mediada por Agrobacterium}

Resumo Os protocormos são estruturas anatômicas únicas: são similares aos rizoides e se formam por hastes jovens de orquídeas sob condições fisiológicas. Os tecidos explantados de orquídeas produzem estruturas chamadas Corpos Similares a Protocormos (PLBs) quando estão expostos a condições apropriadas de crescimento in vitro. Tanto a natureza propagativa dos PLBs como a facilidade com que se generam, fazem com que estas estruturas sejam uma alternativa atrativa, comparativamente a mediada por sementes, para a produção de grandes números de plantas em crescimento. Para aumentar a embriogênesis somática e otimizar o procedimento, se transformaram PLBs de Cattleya maxima utilizando o método de Agrobacterium tumefaciens. O T-DNA carregava um gen de resistencia a Higromicina, um marcador visível (GFP5-GUSA) e um gen de arroz que codificava para o receptor tipo quinasa de embriogênesis somática (SERK), considerado importante na embriogênesis somática. Os PLBs tratados geraram embriões somáticos e desenvolveram plântulas resistentes a Higromicina. A inserção do T-DNA se confirmou por PCR, e a expressão de GFP se observou utilizando um estereomicroscópio de fluorescência. Os PLBs transformados de Cattleya maxima foram mais eficientes em desenvolver embriões somáticos (60-80\%) que os controles não transformados (45-57\%) e este contraste se potencializou em meio Murashige y Skoog (MS) livre de hormônios ( $80 \%$ das plantas transformadas em comparação com $57 \%$ das não-transformadas). Estes resultados apoiam a noção de que SERK desempenha um papel importante na embriogênesis de orquídeas.

Palabras clave: Agrobacterium tumefaciens; Corpos Similares a Protocormos; Transformacao; Orquideas; pCAMBIA; SERK. 


\section{Augusta Cueva}

2005, Environmental Sciences Engineer, Universidad Técnica Particular de Loja, Ecuador.

2012, PhD Degree in Biomolecular and Genetic Sciences "Somatic Embryogenesis in Ecuadorian Orchids", University of Pavia, Italy 2005-2018, Professor at the Biological Sciences Department, Universidad Técnica Particular de Loja, Ecuador.

\section{Rino Cella}

1968 MSc in Biological sciences.

1969-1970 Attendance of a course in "Industrial Microbiology". Postdoc fellow (1972-74) at Dalhousie University, Halifax, CDN, and (1974-75) at Botanical Laboratories, University of Leicester, UK.

1975-1983 Research fellow at Institute of Biochemical Evolutionary Genetics, CNR, Pavia, Italy.

1983-1994 Associate professor of Plant physiology at the University of Pavia.

1994-2016 Professor of Plant physiology at the University of Ferrara and Pavia (retired). 